\title{
Electrophysiological and auditory behavioral evaluation of individuals with left temporal lobe epilepsy
}

\author{
Caroline Nunes Rocha', Carmen Silvia Molleis Galego Miziara², \\ Maria Luiza Giraldes de Manreza ${ }^{3}$, Eliane Schochat ${ }^{4}$
}

\begin{abstract}
The purpose of this study was to determine the repercussions of left temporal lobe epilepsy (TLE) for subjects with left mesial temporal sclerosis (LMTS) in relation to the behavioral testDichotic Digits Test (DDT), event-related potential (P300), and to compare the two temporal lobes in terms of P300 latency and amplitude. We studied 12 subjects with LMTS and 12 control subjects without LMTS. Relationships between P300 latency and P300 amplitude at sites $C 3 A 1, C 3 A 2, C 4 A 1$, and C4A2, together with DDT results, were studied in inter-and intra-group analyses. On the DDT, subjects with LMTS performed poorly in comparison to controls. This difference was statistically significant for both ears. The P300 was absent in 6 individuals with LMTS. Regarding P300 latency and amplitude, as a group, LMTS subjects presented trend toward greater P300 latency and lower P300 amplitude at all positions in relation to controls, difference being statistically significant for C3A1 and C4A2. However, it was not possible to determine laterality effect of P300 between affected and unaffected hemispheres.
\end{abstract}

Key words: epilepsy, event-related potentials P300, mesial temporal sclerosis.

\section{Avaliação eletrofisiológica e comportamental da audição em individuos com epilepsia em lobo temporal esquerdo}

\section{RESUMO}

O objetivo deste estudo foi determinar a repercussão da epilepsia de lobo temporal esquerdo (LTE) em indivíduos com esclerose mesial temporal esquerda (EMTE) em relação à avaliação auditiva comportamental-Teste Dicótico de Dígitos (TDD), ao Potencial Evocado Auditivo de Longa Latência (P300) e comparar o P300 do lobo temporal esquerdo e direito. Estudamos 12 indivíduos com EMTE (grupo estudo) e 12 indivíduos controle com desenvolvimento típico. Analisamos as relações entre a latência e amplitude do P300, obtidos nas posições C3A1,C3A2,C4A1 e C4A2 e os resultados obtidos no TDD. No TDD, o grupo estudo apresentou pior desempenho em relação ao grupo controle, sendo esta diferença estatisticamente significante em ambas as orelhas. Para o P300, observamos que em seis indivíduos com EMTE o potencial foi ausente. Para a latência e amplitude, verificamos que estes indivíduos apresentaram uma tendência ao aumento da latência

Correspondence

Caroline Nunes Rocha University of São Paulo School of Medicine

Rua Cipotanea 51 - Cidade Universitária 05360-000 São Paulo SP - Brasil

E-mail: carolrocha@usp.br

\section{Support}

This study was supported by Fundação de Amparo a Pesquisa de

São Paulo - FAPESP. Process: 14301-3

Received 27 April 2009

Received in final form 29 July 2009

Accepted 10 September 2009 e redução da amplitude para todas as posições em relação ao grupo controle, sendo estatisticamente significante em C3A1 e C4A2. Contudo, não foi possível determinar efeito de lateralidade do P300 entre o hemisfério afetado e não-afetado.

Palavras-chave: epilepsia, potencial evocado P300, esclerose mesial temporal.

According to the International League against Epilepsy (ILAE) and the International Bureau for Epilepsy, epilepsy is defined as "a disorder of the brain character- ized by an enduring predisposition to generate epileptic seizures and by the neurobiologic, cognitive, psychological, and social consequences of this condition". The defi- 
nition of epilepsy requires the occurrence of at least one epileptic seizure ${ }^{1}$. Epilepsy affects $1-1.5 \%$ of the population worldwide. Even in developed countries, where antiepileptic drugs (AEDs) widely available, $30-40 \%$ of individuals with epilepsy continue to have seizures that are not adequately controlled by pharmacotherapy ${ }^{2}$. The most common cause of refractory temporal lobe epilepsy and symptomatic temporal lobe epilepsy is mesial temporal sclerosis (MTS), described by Sommer in 1980, that occurs in $20 \%$ of patients with epilepsy of which, approximately $65 \%$ present mesial temporal lobe epilepsy ${ }^{3}$. MST is a relatively homogeneous lesion that involves a variable degree of selective neuronal loss in the CA1, CA3, and CA4 hippocampal regions, with limited to pronounced involvement of the amygdala and parahippocampal gyrus. MTS is diagnosed based on typical magnetic resonance imaging (MRI) findings in the hippocampus, as well as on electroencephalogram (EEG) findings. Information processing (encoding, selection, memory, language, attention and decision making) has been investigated by means of behavioral tests (auditory processing tests, e.g., dichotic listening) and auditory event-related potentials (ERPs, e.g., P300), which reflect the involvement of cortical activity in the discrimination abilities, integration, and attention of the brain ${ }^{4,5}$. The assessment of P300 is a clinically relevant method of evaluating the cognitive function of epilepsy patients ${ }^{6,7}$. It is an objective, noninvasive procedure and is the recommended standard for the clinical evaluation of cognitive processing. Changes in P300 latency can differ according to the epileptic syndrome, duration, and seizure frequency ${ }^{8-10}$. Nevertheless, most studies have shown abnormalities in ERPs, especially P300, in various neurological diseases as well as in patients with epilepsy. The cause of such abnormalities in patients with epilepsy is unknown. Some authors believe that approximately $90 \%$ of patients present abnormal P300 latency, and that the frequency of seizures and AEDs likely contributes to the deterioration in some cases ${ }^{11,12}$. Due to the lesion location and electrical discharges to be related to the final point of the auditory pathway, as well as to possible specific cognitive deficits that the illness can cause, the use of complementary examinations is fundamental in order to assess the cognitive damage in epileptic subjects. This can facilitate the differential diagnosis, as well as contributing to the development of new therapeutic techniques and rehabilitation processes.

Therefore, the objective of this study was to determine the repercussions of left temporal lobe epilepsy for the Dichotic Digits Test (DDT) and ERP P300, as well as to compare the latency and amplitude of P300 in the left (affected) temporal lobe with that observed in the right (unaffected) temporal lobe among subjects with left temporal lobe epilepsy. Thus, we aimed to identify a poten- tial relationship of laterality between the lesion location and alterations in the P300.

\section{METHOD}

This study was carried out in the Auditory Processing Laboratory, after approval of University of São Paulo School of Medicine Ethics Committee (Protocol no. 052/05). All participants provided written informed consent to participate in the study.

\section{Subjects}

The following criteria were used in order to select the study sample:

Inclusion criteria: Over 18 years of age and below the age of 50; left temporal lobe epilepsy attributed to LMTS, diagnosed through functional MRI and EEG.

Exclusion criteria: Previous submission to surgical intervention in the cerebral region; other neurological disorders, psychiatric disorders, or associated pathologies; history of auditory problems.

Twenty-four subjects were evaluated: 12 in the control group (subjects with typical development) and 12 in the study group, which were selected through analysis of the records on file at Epilepsy Clinic of the Hospital das Clínicas, University of São Paulo School of Medicine. Age in the control group ranged from 20 to 25 years

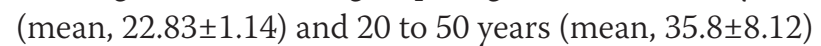
in the study group. Gender distribution was the same between female and male in study group - gender differences must be considered for reasons of sexual dimorphism in the human hippocampal formation - being six subject for each gender ${ }^{13}$.

\section{Procedures}

The subjects underwent a basic audiological evaluation, which consisted of otoscopy, in order to ensure ideal conditions for the accomplishment of the tests. Subsequently, a hearing screening was carried out in order to rule out hearing loss. The auditory screening was performed using an audiometer (model GSI 61; Grason-Stadler, Madison, WI, USA), in a soundproof booth. Hearing thresholds, as well as speech recognition, were measured in both ears prior to further testing.

The next step consisted of dichotic test, which reflects the auditory figure-ground ability and binaural integration for linguistic sounds, in order to determine the perceptual asymmetry for linguistic stimuli. The test was applied using a compact disc player, connected to the audiometer and adapted to supra-aural earphones ${ }^{14}$. The dichotic test was administered at $50 \mathrm{~dB}$ HL related to the speech recognition for each subject in order to control threshold differences between the two ears and across subjects. 
Throughout the test, two digits were presented to each ear and the subject was instructed to repeat both pairs of digits following each presentation, and to guess if not sure of any heard digit. The test consisted of 20 pairs of double digits for a total number within each ear of 40 digits. The number of the repeated digits correctly heard for each ear was recorded and converted to percent correct.

The following step was electrophysiological evaluation through investigation of P300 using a two-channel electroneuromyograph (Biologic Traveler Electrodiagnostic Testing System; Biological Systems Corp., Mundelein, IL, USA).

The oddball paradigm was used in P300 recordings. This paradigm is based on distinguishing a target stimuli repeated randomly and less frequently from the nontarget stimuli of frequent repetition. The subject is asked to count the stimuli when he/she encounters the same. Monoaural auditory stimuli were presented in the earphones, delivered to each ear separately, $1000 \mathrm{~Hz}$ for the frequent stimuli (non-target) and $1500 \mathrm{~Hz}$ for the rare (target) stimuli (with a probability of $20 \%$ ), intensity of both stimuli of $75 \mathrm{~dB}$ HL. The electrode sites used were C3A1, C3A2, C4A1, C4A2, and Fpz, the last as a ground. Electrodes impedances were always less than $5 \mathrm{k} \Omega$.

According to Musiek and Lee ${ }^{15}$, the age range presented in the study should not suffer maturational or degenerative influences in P300 latency or amplitude.

\section{Statistical analysis}

For the dichotic test, we used two forms of analysis: comparing the mean score obtained by the study group with that obtained by the control group (inter-group analysis); and comparing the results obtained in the right ears (contralateral to the lesion) with those obtained in the left ears (ipsilateral to the lesion), in order to identify possible perceptual asymmetry for linguistic stimuli in the study group (intra-group analysis).

The result and analysis of the ERP were always related to the P300 component. In both groups, we analyzed mean P300 latency and amplitude, drawing comparisons between the two groups. As for the dichotic test, we also performed an intra-group analysis in which we compared the results obtained in the right ears with those obtained in the left ears.

Student's t-test was used for the statistical comparison between two independent samples. The level of significance was set at 0.05 , and significant values are designated with an asterisk (*).

\section{RESULTS}

\section{Individual characteristics}

Clinical profiles of each subject (study group) and the performance data related to the tests applied is shown in Table 1.
All subjects presented right-hemispheric dominance. The average education level in the study group was lower than in the control group: 6 subjects had less than eight years of schooling; one had exactly eight years of schooling; 4 had completed high school; and 1 had completed college. With relation to seizure frequency, the observed mean of the subjects with MTS was 2 partial seizures per month. All subjects were receiving AEDs, in monotherapy or polytherapy.

\section{Dichotic test}

In Table 2 we present the performance (in percentage of correct responses) obtained for the two groups on the dichotic test. Performance was significantly better in the control group. However, in the study group, lesion was not found to have any effect on the test results.

\section{P300 evaluation}

A comparative study of latency and amplitude measures of P300 was carried out in the control and the study groups (inter-group analysis), together with a comparative study of the results obtained on the right and left hemispheres (intra-group analysis).

For the study group, P300 was not recorded in 6 individuals.

Table 3 shows the latency and amplitude measures of the P300 for the values of mean, median and standard deviation obtained in the control and study group respectively, according to sites C3A1,C4A1,C4A2, and C3A2.

In the comparison between groups, a trend toward greater mean latency and lower mean amplitude was observed in the study group (with exception of amplitude at C3A2). Using Student's t-test to determine the significance of findings, we found that this difference was not statistically significant at all positions, as Table 4 shows.

The results of the comparative analysis between the right and left hemispheres are shown in Table 5.

In the control group, we observed a trend toward earlier appearance of P300 in left hemisphere. The amplitude was greater in the ipsilateral pathways, that is, left ear/ left hemisphere (C3A1) and right ear/right hemisphere (C4A2), in relation to contralateral pathways.

The pattern observed in the control group was not observed in the study group.

\section{DISCUSSION}

Cognitive alterations are observed in epileptic subjects in variable degrees and are generated by multiple factors.

We analyzed the comparison between performance of subjects in both groups on the dichotic test and identified statistically significant differences between the control and study groups. These findings are in agreement 


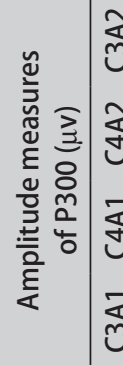

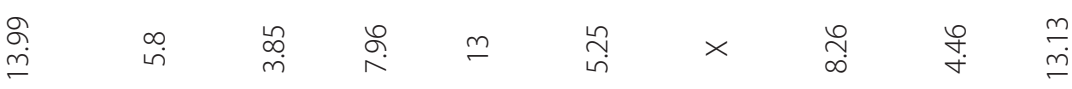

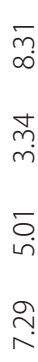

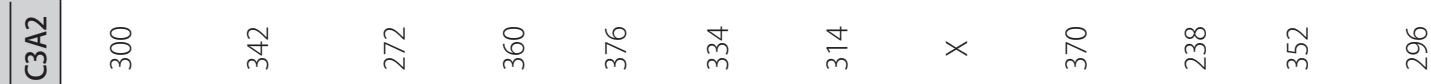
๗ 站

¿্ণ \& n $\stackrel{n}{n} \quad \stackrel{\infty}{n}$ $\stackrel{\infty}{\curvearrowright}$ \&

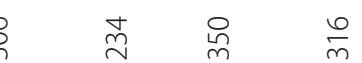
8

$\times$ $\stackrel{\infty}{m} \quad \stackrel{\infty}{m}$ $\stackrel{\infty}{\infty} \stackrel{\infty}{\sim}$ $\stackrel{\infty}{\sim}$

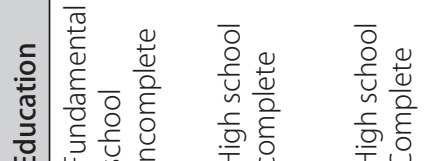

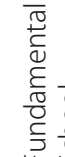

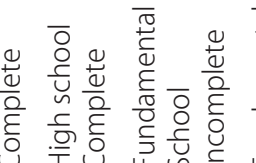

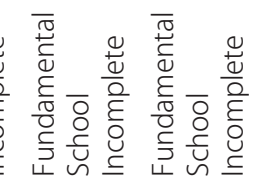

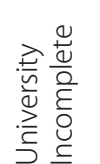

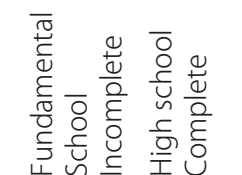

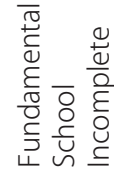


Table 2. Average response (in percent-correct performance) obtained for the dichotic digits test and values of the statistical test.

\begin{tabular}{lccccc}
\hline & \multicolumn{2}{c}{ RE (\%) } & & \multicolumn{2}{c}{ LE (\%) } \\
\cline { 2 - 3 } \cline { 5 - 6 } & Control group & Study group & & Control group & Study group \\
\hline Mean & 97.71 & 81.67 & & 99.17 & 83.75 \\
Median & 97.5 & 91.25 & & 100 & 92.5 \\
SD & 1.67 & 22.01 & & 1.23 & 20.16 \\
t-Test & $\mathrm{p}=0.0238^{*}$ & & & $\mathrm{p}=0.0226^{*}$ & \\
\hline
\end{tabular}

RE: right ear; LE: left ear; SD: standard deviation; *Indicates significant differences, $p \leq 0.05$.

Table 3. Latency and amplitude measures of the P300 wave-form in the control group.

\begin{tabular}{|c|c|c|c|c|c|c|c|c|c|}
\hline \multirow[b]{2}{*}{ Groups } & & \multicolumn{3}{|c|}{ Latency (ms) } & \multirow[b]{2}{*}{$\mathrm{C} 3 \mathrm{~A} 2$} & \multicolumn{4}{|c|}{ Amplitude $(\mu v)$} \\
\hline & & C3A1 & C4A1 & $\mathrm{C} 4 \mathrm{~A} 2$ & & C3A1 & C4A1 & $\mathrm{C} 4 \mathrm{~A} 2$ & $\mathrm{C} 3 \mathrm{~A} 2$ \\
\hline \multirow[t]{3}{*}{ Control group } & Mean & 291.50 & 309.33 & 307.33 & 298.00 & 9.85 & 8.92 & 9.00 & 6.92 \\
\hline & Median & 301 & 312 & 320 & 303 & 9.115 & 7.185 & 7.295 & 6.18 \\
\hline & SD & 37.53 & 28.38 & 37.46 & 37.03 & 5.18 & 5.10 & 4.03 & 3.29 \\
\hline \multirow[t]{3}{*}{ Study group } & Mean & 327.08 & 321.17 & 343.58 & 328.67 & 7.10 & 7.51 & 7.01 & 8.28 \\
\hline & Median & 327 & 326 & 351 & 338 & 7.21 & 5.62 & 3.34 & 7.67 \\
\hline & SD & 38.27 & 40.36 & 48.37 & 45.56 & 3.83 & 4.85 & 4.62 & 3.60 \\
\hline
\end{tabular}

LE: left ear; RE: right ear; C3: left hemisphere; C4: right hemisphere; SD: standard deviation; ms: milliseconds; $\mu$ v: microvolts

Table 4. Latencies measures of the P300 wave-form for control group and study group for each recording condition.

\begin{tabular}{|c|c|c|c|c|c|c|c|}
\hline \multirow[b]{2}{*}{ Side } & \multirow[b]{2}{*}{ Groups } & \multicolumn{3}{|c|}{ Latencies (ms) } & \multicolumn{3}{|c|}{ Amplitudes $(\mu v)$} \\
\hline & & Mean & SD & $\mathrm{P}$ (T-Test) & Mean & SD & $\mathrm{P}$ (T-Test) \\
\hline C3, LE & $\begin{array}{l}\text { Control } \\
\text { Study }\end{array}$ & $\begin{array}{l}291.50 \\
327.08\end{array}$ & $\begin{array}{l}37.53 \\
38.37\end{array}$ & $0.0326^{*}$ & $\begin{array}{l}9.85 \\
5.92\end{array}$ & $\begin{array}{l}5.18 \\
4.43\end{array}$ & $0.0583^{*}$ \\
\hline $\mathrm{C} 3, \mathrm{RE}$ & $\begin{array}{l}\text { Control } \\
\text { Study }\end{array}$ & $\begin{array}{l}309.33 \\
321.17\end{array}$ & $\begin{array}{l}28.38 \\
40.36\end{array}$ & 0.4160 & $\begin{array}{l}8.92 \\
7.51\end{array}$ & $\begin{array}{l}5.10 \\
4.85\end{array}$ & 0.4947 \\
\hline$C 4, R E$ & $\begin{array}{l}\text { Control } \\
\text { Study }\end{array}$ & $\begin{array}{l}307.33 \\
343.58\end{array}$ & $\begin{array}{l}37.46 \\
48.37\end{array}$ & $0.0526^{*}$ & $\begin{array}{l}9.00 \\
5.26\end{array}$ & $\begin{array}{l}4.03 \\
5.06\end{array}$ & $0.0580^{*}$ \\
\hline C4, LE & $\begin{array}{l}\text { Control } \\
\text { Study }\end{array}$ & $\begin{array}{l}298.00 \\
328.67\end{array}$ & $\begin{array}{l}37.03 \\
45.56\end{array}$ & 0.0869 & $\begin{array}{l}6.92 \\
7.59\end{array}$ & $\begin{array}{l}3.29 \\
4.18\end{array}$ & 0.6689 \\
\hline
\end{tabular}

LE: left ear; RE: right ear; C3: left hemisphere; C4: right hemisphere SD: standard deviation; ms: milliseconds; $\mu$ v: microvolts; *Indicates significant differences, $p \leq 0.05$.

with those of Gadea-Doménech and Espert-Tortajada ${ }^{16}$ and Lundberg et al. ${ }^{17}$, who evaluated children with neurological alterations using a dichotic listening test, finding statistically significant alterations for the quantitative and qualitative analyses in relation to the control group.

A study carried out by Glowinski ${ }^{18}$ suggested that a minimum electrical discharge, which occurs frequently in subjects with MTS, can harm the memory functioning. Gevins et al. ${ }^{19}$ observed structural, histopathological and biochemical alterations, commonly associated with alterations of blood flow in epileptic subjects. This explains the difference between epileptic and nonepileptic subjects in terms of stimuli processing, being that the fast, located and lateralized processing promoted by the neural net would only appear in normal individuals.

In this study, there was effect of the lesion, that is, a greater than 10\% difference between the correct responses obtained in the right and left ears, in only 3 subjects in the study group. This indicated that, in their majority, there was no significant effect of lesion to this test.

In P300 parameters, we found that P300 was absent in 6 study group subjects. Among those 6, site C3A1 was absent in 2, site C3A2 was absent in one, and site C4A2 was absent in 3 . The same was not observed among the control group subjects, in whom P300 was present at all electrode sites tested in both ears. Authors have also re- 
Table 5. Hemispheric comparison for Latency and Amplitude of the P300 in the control and study groups.

\begin{tabular}{|c|c|c|c|c|c|c|c|}
\hline & \multirow[b]{2}{*}{ Hemisphere } & \multicolumn{3}{|c|}{ Latency (ms) } & \multicolumn{3}{|c|}{ Amplitude $(\mu v)$} \\
\hline & & Mean & SD & $\mathrm{P}$ (T-Test) & Mean & SD & $\mathrm{P}$ (T-Test) \\
\hline \multicolumn{8}{|c|}{ Control } \\
\hline LE & $\begin{array}{l}\text { Left } \\
\text { Right }\end{array}$ & $\begin{array}{l}291.50 \\
309.33\end{array}$ & $\begin{array}{l}37.53 \\
28.38\end{array}$ & 0.0946 & $\begin{array}{l}9.85 \\
8.92\end{array}$ & $\begin{array}{l}5.18 \\
5.10\end{array}$ & 0.2817 \\
\hline RE & $\begin{array}{l}\text { Left } \\
\text { Right }\end{array}$ & $\begin{array}{l}298.00 \\
307.33\end{array}$ & $\begin{array}{l}37.03 \\
37.46\end{array}$ & 0.3581 & $\begin{array}{l}6.92 \\
9.00\end{array}$ & $\begin{array}{l}3.29 \\
4.03\end{array}$ & $0.0143^{*}$ \\
\hline \multicolumn{8}{|c|}{ Study } \\
\hline LE & $\begin{array}{l}\text { Left } \\
\text { Right }\end{array}$ & $\begin{array}{l}326.25 \\
321.17\end{array}$ & $\begin{array}{l}37.08 \\
40.36\end{array}$ & 0.3755 & $\begin{array}{l}5.92 \\
7.51\end{array}$ & $\begin{array}{l}4.43 \\
4.85\end{array}$ & 0.2056 \\
\hline RE & $\begin{array}{l}\text { Left } \\
\text { Right }\end{array}$ & $\begin{array}{l}328.25 \\
343.58\end{array}$ & $\begin{array}{l}45.11 \\
48.23\end{array}$ & 0.2149 & $\begin{array}{l}7.59 \\
4.18\end{array}$ & $\begin{array}{l}5.26 \\
5.06\end{array}$ & 0.1160 \\
\hline
\end{tabular}

LE: left ear; RE: right ear; SD: standard deviation; ms: milliseconds; $\mu \mathrm{v}$ : microvolts; ${ }^{\prime}$ Indicates significant differences, $p \leq 0.05$.

ported this absence in subjects with cerebral disorders ${ }^{20,21}$. An absent P300 cannot be conclusively linked to a brain lesion. However, we submit that the tendency for an absent P300 to occur is greater in individuals with brain lesions than in the normal population. A number of studies have shown greater P300 latency and reduced P300 amplitude in epileptic patients, thereby corroborating our findings ${ }^{10,22-24}$.

The study group showed a statistically significant trend toward greater P300 latency and lower P300 amplitude. Knight et al. ${ }^{25}$ compared six subjects with lesion of the temporoparietal junction to six subjects with parietal lesion. Their study showed that on temporal group, amplitude was markedly reduced in comparison to parietal group, which presented results similar to those of normal subjects of the control group of this study.

Ebner et al. ${ }^{26}$ affirm that the latency increased and the amplitude reduction can be related to neurophysiological alterations and not only and necessarily associate to a cerebral disorder as showed in this study, probably because cognitive functions reflected with P300 latencies decline in relation with duration and frequency of every kind of seizure, AEDs and seizure types as shown by Sun et al. ${ }^{27}$. Some authors believe that the seizure frequency can negatively affect cognitive functions. Nevertheless, Soysal et al..$^{28}$ and Celebisoy et al. ${ }^{10}$ found no such correlation. Also, Ozmenek et al. ${ }^{24}$ and Soyal et al. ${ }^{28}$ found that chronic epilepsy patients had more prolonged P300 latencies than did normal individuals and there were significant differences on the basis of seizure type and anticonvulsant concentration. In the latest study, P300 latencies were longer in idiopathic primary generalized epilepsy than in secondary generalized epilepsy. However, Enoki et al. ${ }^{29}$ reported that the type of epilepsy had no effect on the latency of P300.

Another influence that could alter P300 and cognitive function is epilepsy duration. Sun et al. ${ }^{27}$ found that epilepsy duration was associated with delayed P300 latency. These findings were not confirmed in another studies ${ }^{10,30}$.

It is known that P300 latency can increase when there is difficulty in the oddball paradigm ${ }^{15}$. However, in our study, all subjects were capable to discriminate the target stimuli from amongst the series of sounds presented.

All of the variables shown (including daily dosages of AEDs) could damage the P300 wave-form. However, in the present study, it was not possible to determine which variable or variables damage directly or indirectly the P300 wave-form, once separate investigation was not the purpose of this study. The findings of the amplitude reduction and latency increase in our study group appear to be the result of reduced neural capacity for processing the oddball paradigm information, even when the pathologic subjects could complete the task. The P300 amplitude reduction in these subjects could indicate that a smaller number of neurons were functioning or that the intensity of neural firing was diminished as stated by Musiek et al. ${ }^{31}$.

In relation to laterality effect, in the control group there was a trend toward earlier appearance of P300 in the left hemisphere when compared to the right. There was also a difference in relation to the amplitude, which was greater in ipsilateral than in contralateral pathways.

The same situation was not observed in the study group. Therefore, there was no laterality effect, despite the means indicating precocious latency and a greater amplitude in contralateral, in comparison to ipsilateral pathways.

These results can be explained by the fact that both hemispheres participate in this cognitive processing task, and that the corpus callosum is an integral part of the circuitry. Damage to a nerve cell means that the cell can neither send nor receive impulses. Therefore, if one hemisphere is damaged and the P300 is similarly affected for 
either ear or electrode site, it might mean that the normal hemisphere was in some way dependent on or influenced by the abnormal function of the damaged hemisphere. This must be the hypothesis to explain the lack of a laterality effect limited to the affected hemisphere. This supports the view that P300 reflects an integration of function of various areas of the brain.

Studies conducted by Ebner et al. ${ }^{26}$ and Musiek et al. ${ }^{31}$ did not affirm any laterality effect on the studied subjects, but they do affirm the sensitivity of the P300 for cognitive disorders as well as for focal cerebral injuries.

We know, however, that other factors might have been responsible or might have intervened in a joint manner for the performance observed in the study group: duration and frequency of the seizures; neurophysiological factors and specific drugs used; and education level.

These factors must be better investigated, separately and in a larger sample, using a method that furthers the understanding of the alterations that occur in the auditory pathway, both functional and structural, in subjects with left temporal lobe epilepsy.

In conclusion, the evaluation of auditory behavioral and P300 in subjects with left temporal lobe epilepsy allowed the following conclusions: (1) Subjects with epilepsy for MTS present with worse performance for the auditory figure-ground ability and binaural integration for linguistic sounds when compared with control group subjects. There was no correlation between the performance obtained by the subjects of the study group and the location of the injury (left temporal lobe). (2) There was a greater prevalence of $\mathrm{P} 300$ absence in subjects with MTS epilepsy, being that P300 latency was greater and P300 amplitude was lesser at all C3A1 and C4A2 positions when compared with the control group. (3) It was not possible to determine the laterality effect between the affected and unaffected hemispheres in the subjects with cerebral injury limited to one hemisphere.

\section{REFERENCES}

1. Fisher RS, Van Emde Boas W, Blume W, et al. Epileptic seizures and epilepsy: definitions proposed by the International League Against Epilepsy (ILAE) and the International Bureau for Epilepsy. Epilepsia 2005;46:470-472.

2. Engel Jr J, Wiebe S, French J, et al. Practice parameter: temporal lobe and localized neocortical resections for epilepsy. Neurology 2003;60:538-547.

3. Panayiotopoulos CP. A clinical guide o epileptic syndromes and their treatment. $2^{\text {nd }}$ ed. London: Springer, 2007.

4. Kraus N, McGee T. Auditory event-related potentials. In: Katz J (Ed). Handbook of clinical auditory. $4^{\text {th }}$ Ed. Baltimore: Williams e Wilkins 1994:406-426.
5. Schochat E, Scheuer $\mathrm{Cl}$, Andrade ER. ABR and auditory P300 findings in children with ADHD. Arq Neuropsiquiatr 2002;60:742-747.

6. Sun W, Wang Y, Wang W. The significance of event-related potential on epileptics with AEDs. J Clin Neurophysiol 2007;24:271-276.

7. Duman Ö, Kizilay F, Fettahoglu C, Ozkaynak S, Haspolat S. Electrophysiologic and neuropsychologic evaluation of patients with centrotemporal spikes. Int J Neurosci 2008;118:7:995-1008.

8. Drake ME, Huber J, Pakalnis A, Phillips BB. Neuropsychological and event-related potential correlates of nonepileptic seizures. Neurosciences 1993;5: 102-104.

9. Grunwald T, Beck H, Lehenertz K, et al. Limbic P300s in temporal lobe epilepsy with and without Ammon's horn sclerosis. Eur J Neurosci 1999;11:1899-1906.

10. Celebisoy N, Kisabay A, Gökçay F, Gökçay A. Evaluating cognitive functions with visual and auditory number assays and P300 in children with epilepsy. Brain Dev 2005;27:253-258.

11. Kubota F, Nobuyoshi N, Kifune A, Shiihara F, Takahashi A. Study on P300 latencies and amplitudies of adult epilepsy patients medicated and unmedicated patients. Epilepsia 1997;38(Suppl 3):S242.

12. Pimentel T, Foreid J. P300 in patients with TLE. Epilepsia 1998;39(Suppl 2): S50.

13. Savic I, Engel J Jr. Sex differences in patients with mesial temporal lobe epilepsy. J Neurol Neurosurg Psychiatry 1998;65:910-912.

14. Pereira LD, Schochat E. Processamento auditivo central. São Paulo: Lovise, 1997.

15. Musiek FE, Lee WW. Auditory middle and late potencial. In: Musiek FE, Rintelmann WF (Eds). Contemporary perspectives in hearing assessment. Boston: Allyn and Bacon 1999:239-267.

16. Gadea-Doménech M, Espert-Tortajada R. Aplicaciones de la escucha dicótica verbal a la clínica neurológica y neuropsiquiátrica. Rev Neurol 2004;39:74-80.

17. Lundberg S, Frylmark A, Eeg-Olofsson O. Children with rolandic epilepsy have abnormalities of oromotor and dichotic listening performance. Dev Med Child Neurol 2005;47:603-608.

18. Glowinski H. Cognitive deficits in temporal lobe epilepsy: an investigation of memory functioning. J Nerv Ment Dis 1973;157:129-137.

19. Gevins AS, Schaffer RE, Doyle JC, et al. Shadows of thought: shifting visuomotor task. Science 1983; 200:97-99.

20. Musiek FE. Auditory evoked response in site of lesion assessment. In: Ritelmann WF (Ed). Hearing Assessment. Boston: Allyn and Bacon 1991;383-427.

21. McPherson, D. Late potentials of the auditory system. San Diego, Singular Publishing Group 1996:75-100.

22. Abubakr A, Wambacq I. The localizing value of auditory event-related potential (P300) in patients with medically intractable temporal lobe epilepsy. Epilepsy Behav 2003;4:692-701.

23. Gokcay A, Celebisoy N, Gokcay F, Atac C. Cognitive functions evaluated by P300 and visual and auditory number assays in children with childhood epilepsy with occipital paroxysms (CEOP). Seizure 2006;15:22-27.

24. Ozmenek OA, Nazliel B, Leventoglu A, Bilir E. The role of event related potentials in evaluation of subclinical cognitive dysfunction in epileptic patients. Acta Neurol Belg 2008;108:58-63.

25. Knight R, Scabini D, Woods D, Clayworth C. Contributions of temporal-parietal junction to the human auditory P3. Brain Research 1989;502:109-116.

26. Ebner A, Haas JC, Lucking CH, et al. Event-related brain potentials (P300) and neuropsychological deficit in patients with focal brain lesions. Neurosci Lett 1986;64:330-334.

27. Sun W, Wang Y, Wang W, Wu X. Attention changes in epilepsy patients following 3-month topiramate or valproate treatment revealed by event-related potential. Int J Psychophysiol 2008;68:235-241.

28. Soysal A, Atakli D, Atay T, et al. Auditory event-related potentials (P300) in partial and generalized epileptic patients. Seizure 1999;8:107-110.

29. Enoki H, Sanada S, Oka E, Ohtahara S. Effects of high-dose antiepileptic drugs on event-related potentials in epileptic children. Epilepsy Res 1996;25:59-64.

30. Sunaga Y, Hikima A, Otsuka T, Nagashima K, Kuroume T. P300 event-related potentials in epileptic children. Clin Electroencephalogr 1994;25:13-17.

31. Musiek FE, Baran J, Pinheiro M. P300 results in patients with lesions of the auditory areas of the cerebrum. J Am Acad Audiol 1992;3:5-15. 